\title{
Increased Susceptibility of Riboflavin Deficient Rats to Galactose Gataract
}

Recent studies have shown that the glutathione reductase activity of human red blood cells is strongly dependent upon the state of riboflavin nutrition ${ }^{1-3}$. The metabolism of the lens of the eye closely resembles red cell metabolism ${ }^{4}$. Because of the critical role that glutathione reduction appears to play in the defense of lens protein against precipitation as cataracts ${ }^{5,6}$, we have investigated the role of riboflavin intake on lens glutathione reductase activity and on galactose-induced cataract.

When 23-day-old albino rats were placed on riboflavindeficient diet (Nutritional Biochemicals Corp. USA), the average glutathione reductase activity of red cells was found to be $40 \%$ of that of a normal control group which received an identical diet, supplemented, however, with $33 \mathrm{mg}$ of riboflavin $/ \mathrm{kg}$. The glutathione reductase activity of the lens of the rats fed the riboflavin-deficient diet for 21 days was about $75 \%$ that of the enzyme activity in the lens of rats fed the riboflavin-fortified diet. 20 rats which had been on a riboflavin-deficient diet for 21 days were placed on a $68 \%$ galactose diet (Nutritional Biochemicals Corp. USA) deficient in riboflavin. 20 rats which had been receiving the riboflavin-supplemented diet received $68 \%$ galactose diet containing $33 \mathrm{mg}$ riboflavin/ $/ \mathrm{kg}$ diet. They were examined ophthalmoscopically every few days. At appropriate intervals equal numbers of riboflavindeficient and control rats were sacrificed, the degree of cataract formation in the lenses was evaluated visually, and the amount of soluble lens protein, glutathione, glutathione reductase activity and total thiol was determined. The Table shows the results of these studies.

Fifteen days after the feeding of the high-galactose diet deficient in riboflavin had been started, about $60 \%$ of rats developed mature cataracts and the remaining had severe opacity; the lenses of control rats, receiving a highgalactose diet supplemented with riboflavin, showed only slight vacuolization. 3 days later about $90 \%$ of the riboflavin-deficient rats had developed mature cataracts, whereas $80 \%$ of the control rats fed on high-galactose diet fortified with riboflavin, developed only partial subscapular cataracts. However, 26 days after feeding of the high galactose diet with riboflavin had been initiated, about $85 \%$ of control rats had also developed mature cataracts.

It is clear that riboflavin deficiency produces not only decreased lens glutathione reductase activity, but also increases susceptibility to cataract formation. Although it is attractive to suppose that mechanism of the enhanced susceptibility of these animals to cataract formation is diminished capacity to reduce glutathione, other more remote effects of riboflavin deficiency must also be considered. For example, the body weight of riboflavindeficient animals averages $25 \%$ less than that of control animals. Further studies to delineate the role of riboflavin nutrition on susceptibility to cataract formation are clearly indicated, and may prove to be of ultimate clinical importance?

Protein, total thiol and glutathione reductase activity in the lens of rats kept on high galactose diet ${ }^{2}$

\begin{tabular}{|c|c|c|c|c|c|c|c|}
\hline $\begin{array}{l}\text { Days after } \\
\text { feeding } \\
\text { high galactose } \\
\text { diet }\end{array}$ & $\begin{array}{l}\text { No. of } \\
\text { rats }\end{array}$ & Riboflavin & $\begin{array}{l}\text { Protein } \\
\text { Total } \\
\mathrm{mg} / 100 \mathrm{mg} \\
\text { wet wt. }\end{array}$ & $\begin{array}{l}\text { Soluble } \\
\mathrm{mg} / 100 \mathrm{mg} \\
\text { wet wt. }\end{array}$ & $\begin{array}{l}\text { Total thiol } \\
\mu \text { moles } / 100 \mathrm{mg} \\
\text { wet wt. }\end{array}$ & $\begin{array}{l}\text { Glutathio } \\
\text { Units/100 } \\
\text { No FAD }\end{array}$ & $\begin{array}{l}\text { luctase } \\
\text { ret wt. } \\
\text { With FAD }\end{array}$ \\
\hline 0 & $\begin{array}{l}2 \\
2\end{array}$ & + & $\begin{array}{l}30.0 \\
24.8\end{array}$ & $\begin{array}{l}N^{b} \\
N D\end{array}$ & $\begin{array}{l}2.38 \\
2.08\end{array}$ & $\begin{array}{r}12.6 \\
9.2\end{array}$ & $\begin{array}{l}18.9 \\
13.1\end{array}$ \\
\hline 8 & $\begin{array}{l}1 \\
1\end{array}$ & + & $\begin{array}{l}N^{b} \\
N D\end{array}$ & $\begin{array}{l}36.8 \\
40.0\end{array}$ & $\begin{array}{l}\text { ND } \\
\text { ND }\end{array}$ & $\begin{array}{l}24.9 \\
19.0\end{array}$ & $\begin{array}{l}\text { ND } \\
\text { ND }\end{array}$ \\
\hline 20 & $\begin{array}{l}3 \\
3\end{array}$ & + & $\begin{array}{l}28.0 \\
22.0\end{array}$ & $\begin{array}{l}25.6 \\
13.6\end{array}$ & $\begin{array}{l}2.53 \\
1.14\end{array}$ & $\begin{array}{l}18.6 \\
10.4\end{array}$ & $\begin{array}{l}19.9 \\
13.5\end{array}$ \\
\hline 26 & $\begin{array}{l}2 \\
2\end{array}$ & + & $\begin{array}{l}15.6 \\
19.6\end{array}$ & $\begin{array}{l}8.2 \\
4.8\end{array}$ & $\begin{array}{l}0.93 \\
0.43\end{array}$ & $\begin{array}{l}7.6 \\
9.0\end{array}$ & $\begin{array}{r}8.7 \\
10.3\end{array}$ \\
\hline
\end{tabular}

All values are given as mean of the number of rats given in the table. "Conditions of experiments are described in the text. The methods of analysis have been described previously ${ }^{3,6}$. b Not done.

1 D. Glatzle, F. Weber and O. Wiss, Experientia 24, 1122 (1968).

2 E. Beutler, Science 165, 613 (1969).

3 E. Beutler, J. Clin. Invest. 48, 1957 (1969).

4 J. H. JANDL, Ann. Int. Med. 58, 702 (1964).

5 J. H. Kinoshita, Archives Ophthal, 72, 554 (1964).

6 S. K. Srivastava and E. Beutler, Biochem. J. 112, 421 (1969).

7 This investigation was supported in part by Public Health Service Grant No. HE 07449 from the National Heart Institute, and in part by Public Health Service Grant No. HD 01974 from the National Institute of Child Health and Human Development.

8 Chairman, Division of Medicine, City of Hope Medical Center; Clinical Professor of Medicine, University of Southern California, Los Angeles.
Zusammentassung. Bei riboflavinarm ernährten Albinoratten beträgt die Aktivität der Erythrocyten-Glutathionreduktase nur 40\% und diejenige der AugenlinsenGlutathionreduktase $75 \%$ der Aktivität normaler Kontrolltiere und es kommt zu vorzeitigem Auftreten von Katarakten.

\section{S. K. SRivastava and E. Beutler ${ }^{8}$}

Division of Medicine,

City of Hope Medical Center,

Duarte (California 91010, USA), 20 November 1969. 